\title{
魚類の産卵場としての沿岸構造物に関する一考察 〜ハタハ夕産卵場の光と流れについて〜 A STUDY ON COASTAL STRUCTURES AS FISH SPAWNING GROUNDS LIGHT AND FLOWS AROUND SPAWNING GROUNDS OF SANDFISH
}

\author{
丸山修治 $1 \cdot$ 竹田義則 2 永田晋一郎 3 \\ Shuji MARUYAMA, Yoshinori TAKEDA and Shinichiro NAGATA

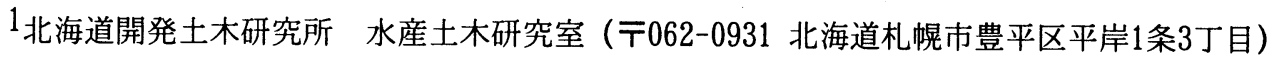 \\ 2 正会員 北海道開発局 釧路開発建設部 釧路港湾建設事務所 ( \\ 3 北海道開発局 札幌開発建設部 深川農業開発事業所（干074-0001 北海道深川市1条15-16）
}

\begin{abstract}
In recent years, spawning of sandfish was observed in gulfweeds adhering to a breakwater in a sandy beach area of the Tomakomai East Port. This suggested that the breakwater served as a reef for sandfish to spawn on.

This study focused on light and flows around a spawning ground of sandfish, for the purpose of adding a function as fish spawning grounds to breakwaters and other coastal structures. The study was based on the results of field surveys conducted in the Tomakomai East Port, where spawning on a breakwater had been observed, and in the Nemuro sea area, which is known as a natural spawning ground.

As a result, it was found that gulfweeds were distributed mainly at depths where light attenuation factors were over the approximate range of 0.05 to 0.09 , although distribution depths differed between the Tomakomai East Port and the Nemuro sea area. Also, in spawning grounds of sandfish, the flow velocity at the time of adhesion of gulfweed embryos was considered to be of higher significance than that during spawning.
\end{abstract}

Key Words : Sandfish, gulfweeds, light,

\section{1.はじめに}

防波堤などの沿岸構造物は，自然岩礁と同様な水 産生物の生息場を形成していることが知られている。 近年, 広域な砂浜海岸である北海道胆振海岸に位置 する苫小牧東港において，防波堤にハ夕ハ夕の産卵 が確認された。これは防波堤がハ夕ハ夕の産卵場と なる岩礁の役割を果たしている可能性を示唆してい る.このことについて伊東ら ${ }^{1)}$ は, ホンダワラ類の ウガノモクという海藻の着生と，その海藻へのハ夕 八夕の産卵について報告している。また，八夕八夕 の産卵で知られている秋田県での産卵基質となって いる海藻も，ほとんどがホンダワラ類である ${ }^{2)}$.

海藻類は陸上の植物と同様に光合成を行って生育 することから, 海域における生育分布範囲は光が届 く水深との関係を把握することが重要であると考え られる.また，ウガノモクのようなホンダワラ類は， 比較的波浪の静穏な場所に分布していることが知ら れている ${ }^{3)}$ 。これは, 幼胚の着底は波当りの強い場 所では困難であると考えられるからである ${ }^{4)}$.この ことから, 幼胚の着生時期の波浪環境を把握するこ
とも重要であると考えられる.

北海道でのハ夕ハ夕の漁獲量は近年減少傾向にあ り, ハ夕ハ夕資源の回復が期待されている. 今後, 防波堤などの沿岸構造物に産卵場が形成される環境 を明らかにし，産卵場を創出することができれば， 水産業に大きく貢献できると考えられる. 本研究で は，防波堤などの沿岸構造物に魚類の産卵場として の機能を付加することを目的に，防波堤に産卵が確 認されている苫小牧東港と天然産卵場として知られ ている根室海域を対象として行った現地調査結果を もとに，八夕ハ夕産卵場の光と流れに着目し検討を 行った.

\section{2. ハタハタの産卵とホンダワラ類}

\section{(1)ハタハ夕の産卵}

八夕ハ夕は, 水深 $250 \mathrm{~m}$ 前後で水温 $1 \sim 2^{\circ} \mathrm{C}$ の深海底 に生息する冷水性の底生魚類である。産卵に関係し てくる年齢は雄雌ともに満2歳（体長 $12 \mathrm{~cm}$ 前後）か らで, 北海道では沿岸水温が $10^{\circ} \mathrm{C}$ 以下になる11月中 
旬頃から水深1〜 10m前後の岩礁域まで回遊し，主 にウガノモクなどのホンダワラ類の枝分かれの部 分に卵塊を産みつける ${ }^{5)}$ 。

\section{（2）ホンダワラ類}

ホンダワラ類は日本の沿岸域に広く分布し，垂 直的には水深 $1 \sim 10 \mathrm{~m}$ 前後の光量が届く範囲で，海 底が岩盤，転石，磁等の着生基質に群落を形成し ている大型の海藻である ${ }^{6)}$. また，丸伊ら ${ }^{7)} に よ$ ると，北海道（小樽市忍路）におけるウガノモク の卵（幼胚）の放出時期は，水温が $13 \sim 15^{\circ} \mathrm{C}$ にな る6月上旬〜7月下旬である。
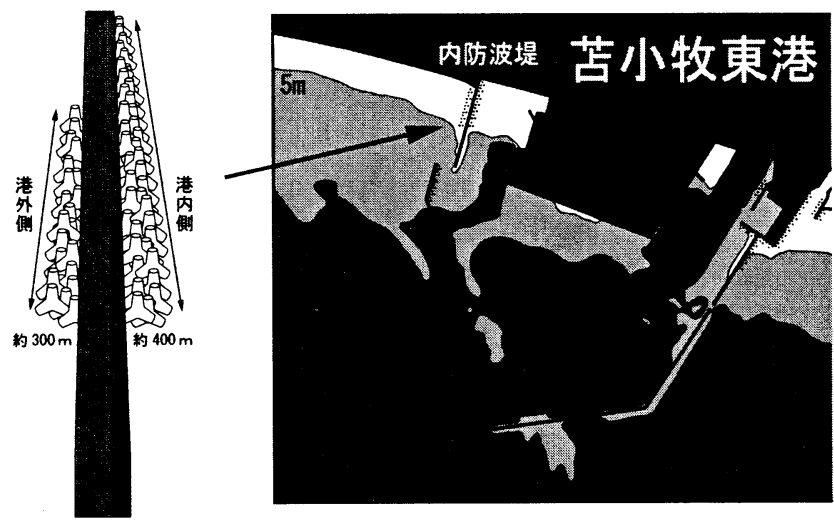

（a）苫小牧東港

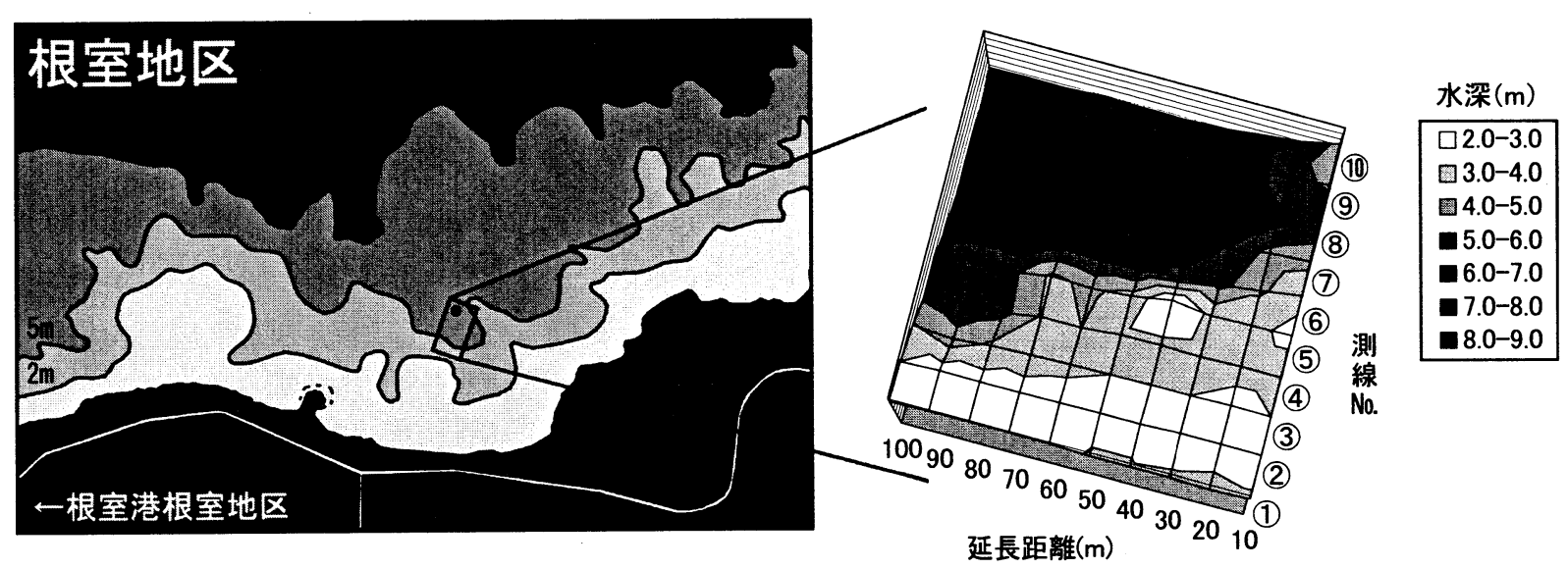

（b） 根室海域

図-1 調查箇所

\section{3. 現地調查内容}

ハ夕ハ夕の産卵が確認されている苫小牧東港内防 波堤周辺と天然の産卵場である根室海域の藻場にお いて, 産卵確認, 照度, 波浪について調査を行い, 各項目について 2 地点間の比較を行った。調查箇所 を図-1に示す。

産卵確認調查は，平成10，11年冬期にダイバーに よる水中撮影及び目視観察を行い, 分布海藻の種類, ハ夕ハ夕の卵塊数及びその卵塊水深について調查を 行った. 苫小牧東港の調査箇所は, 内防波堤の港内 側と港外側に設置している消波ブロックを中心に， 水深 $1 \mathrm{~m}, 2 \mathrm{~m}, 3 \mathrm{~m}, 4 \mathrm{~m}$ の港内側約 $400 \mathrm{~m}$ と港外側約 $300 \mathrm{~m}$ の範囲である.また, 根室海域の調査䇢所は, 調査

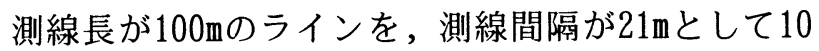
本設定したそのライン上である.

照度調查は，平成11年冬期に直読式光量子計を用 い空中, 水深 $0 \mathrm{~m}, 0.3 \mathrm{~m}, 0.5 \mathrm{~m}, 1.0 \mathrm{~m}$ 以下海底まで $1.0 \mathrm{~m}$ 間隔で光量子量を測定し, 照度と光減衰率を求 めた。苫小牧東港の調查箇所は, 内防波堤の先端部 の港内側と港外側である。 また，根室海域の調査䇢 所は, 産卵確認調查範囲内の地点 (産卵場) と, そ の地点から沖に約 $1.2 \mathrm{~km}$ 離れた地点（沖側）である。
なお，光減衰率は空中観測値を1として求めた.

ハ夕ハ夕産卵場の流速は, 苫小牧東港では平成 9 〜11年の過去3年間の結果を用い，微小振幅波理論 により底面軌道流速を算出した累加出現率 $50 \%$ の未 超過確率流速值（以下，50\%未超過流速）を用いた。 なお波高は, 水深と沿岸構造物を地形とした波高数 值計算により求めた。根室海域では産卵場と水 $20 \mathrm{~m}$ の沖地点を波高計付電磁流速計を用い測定した結果 から，産卵場の有義流速と沖地点の波高との相関を とり，根室港における年間波高出現率推算資料 ${ }^{8)}$ 用いて産卵場の $50 \%$ 未超過流速を算出した。

\section{4. 現地調査結果}

\section{（1）産卵確認調查}

卵塊数と産卵海藻を表-1に示す。苫小牧東港では 平成 $10 ， 11$ 年にそれぞれ $10 ， 16$ 種類の海藻が分布し ていたが，そのうち卵塊が確認された海藻はホンダ ワラ類のウガノモクとアカモクであり，この他にホ ンダワラ類は分布していなかった。海藻別の卵塊数 に着目すると, 平成 10 年はウガノモクが491個でア カモクが445個であり概ね同じであったが, 平成 11 
年はウガノモクが92個に対しアカモクは53個と約 2 倍ウガノモクへの卵塊が多く確認された。なお平成 11年は, 内防波堤周辺を含む港内に刺網等が設置さ れていたこともあり，平成10年の約15\%の卵塊数で あった。一方，根室海域では平成10，11年にそれぞ れ10，15種類の海藻が分布していたが，そのうち卵 塊が確認された海藻はホンダワラ類のネブトモクの みであり，平成10年は194個に対し平成11年は207個 とほぼ同数の卵塊が確認された。なお，ホンダワラ 類はネブトモク以外にフシスジモクが分布していた が，卵塊は確認されなかった。これは秋田県でフシ スジモクへの産卵が確認されていることから，フシ スジモクはネブトモクよりも水深の浅い場所に分布 しているので，ハ夕ハ夕が沖からの回遊時に，水深 の浅い場所に分布しているフシスジモクに来遊する 前に，沖側にネブトモクに産卵してしまったためと 考えられる。

卵塊数と産卵水深帯との関係を図-2に示す。苫小 牧東港では，産卵水深帯は平成10年は $0.5 \mathrm{~m} \sim 3.5 \mathrm{~m}$ に 対し平成 11 年は $0.8 \mathrm{~m} \sim 3.1 \mathrm{~m}$ と概ね同じであった。ま た，平成10年に卵塊が多く確認された範囲は $2.0 \mathrm{~m} 〜$ $2.5 \mathrm{~m} て ゙ ， 3$ 箇所卵塊数が多くなっていたものの，全 体の卵塊数が少ないこともあり各水深帯で同程度で あった。これに対し平成11年に卵塊が多く確認され た範囲は1.0m〜 $1.5 \mathrm{~m}$ と若干の違いがあった。一方， 根室海域では産卵水深帯は平成10年は6.0m〜 7.9mに 対し平成11年は $5.4 \mathrm{~m} \sim 8.7 \mathrm{~m}$ と概ね同じであったが， 卵塊が多く確認された範囲は平成10年は $7.0 \mathrm{~m} \sim 7.3 \mathrm{~m}$ に対し, 平成 11 年は $7.2 \mathrm{~m} \sim 8.2 \mathrm{~m}$ と若干の違いがあっ た。調査海域別の産卵水深帯に着目すると 2 地点間 で大きく異なっていた。

産卵が確認された海藻の本数と産卵水深帯との関 係を図-3に示す. 苫小牧東港では $1.0 \mathrm{~m} \sim 2.5 \mathrm{~m}$ の範囲 が多く，前述の卵塊数が多く確認された水深帯と概 ね同じであった。また，根室海域では7.0m〜 7.9mの 範囲が多く，前述の卵塊数が多く確認された水深帯 と概ね同じであった。

これらのことから，八夕ハ夕は産卵回遊経路上に 産卵海藻となるホンダワラ類が分布していれば，水 深帯に関係なく産卵すると考えられる。

\section{（2）照度調査結果}

各調查地点における水深と照度との関係を図-4に 示す。ホンダワラ類の生育に対する適照度範囲は種 によって異なるが，幼肧期で $2 \mathrm{Kl}$ lux以上，幼体期で 5Klux以上，成体期で5〜10Klux程度でよいとされて いる ${ }^{9}$. 苫小牧東港については港内側と港外側の照 度を平均すると $1.8 \mathrm{~m}$ 程度まで $10 \mathrm{Kl}$ luxの光が到達し， $5 \mathrm{Klux}$ の光は $3.5 \mathrm{~m}$ 程度まで到達していた。産卵基質 として機能していたアカモクとウガノモクの分布水 深は $4.0 \mathrm{~m}$ 程度までであったことから，前出の知見と ほぼ同様の結果が得られた。また，根室海域につい ては産卵場と沖側の照度を平均すると $3.5 \mathrm{~m}$ 程度まで 10Kluxの光が到達し，5Kluxの光は $5.5 \mathrm{~m}$ 程度まで到
表一1 卵塊数と産卵海藻

\begin{tabular}{|c|c|c|c|}
\hline 苫小牧東港全分布海 & $\begin{array}{c}\text { 産卵が確䛳類数 } \\
\text { された海藻 }\end{array}$ & 海藻別の卵塊数 \\
\hline 平成10年 & 10 & 2 & $\begin{array}{c}\text { ウガノモク491個 } \\
\text { アカモク445個 } \\
\text { 計 936個 }\end{array}$ \\
\hline 平成11年 & 16 & 2 & $\begin{array}{c}\text { ウガノモク92個 } \\
\text { アカモク53個 } \\
\text { 計 145個 }\end{array}$ \\
\hline
\end{tabular}

\begin{tabular}{|c|c|c|c|}
\hline 根室海域 & $\begin{array}{c}\text { 全分布海 } \\
\text { 藻種類数 }\end{array}$ & $\begin{array}{l}\text { 産卵が確認 } \\
\text { された海藻 }\end{array}$ & 海藻別の卵塊数 \\
\hline 平成10年 & 10 & 1 & ネブトモク194個 \\
\hline 平成11年 & 15 & 1 & ネブトモク207個 \\
\hline
\end{tabular}
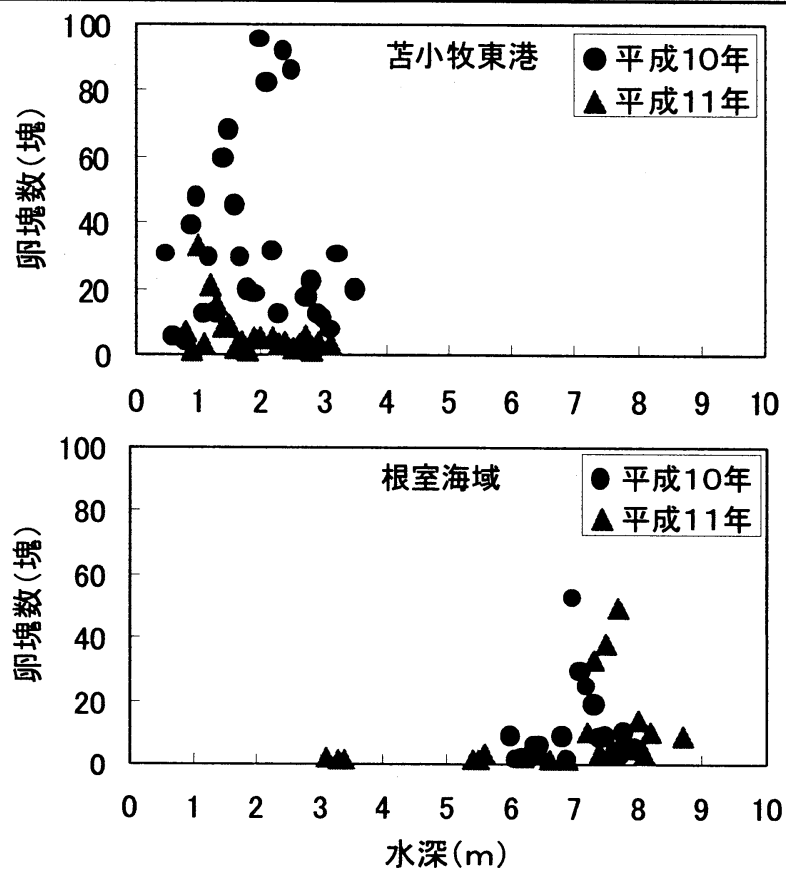

図 -2 卵塊数と産卵水深帯
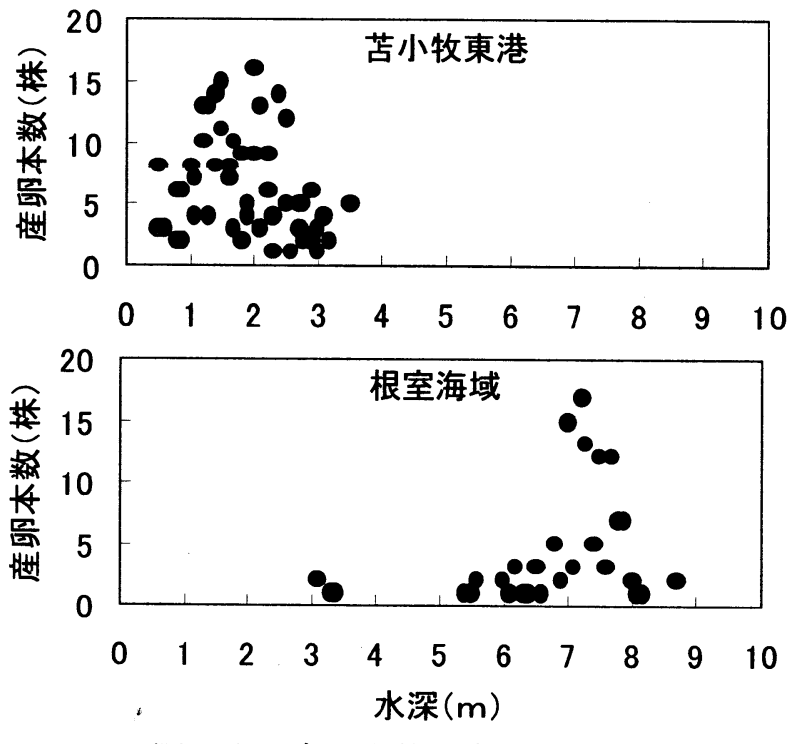

図一 3 産卵本数と産卵水深帯 
達していた。産卵基質として機能していたネブトモ クの分布水深は8.7m程度までであったことから, 本 種は2Klux程度の光でも十分生息可能であるが，時 期的にはさらに深い水深まで光が到達している可能 性があると考えられる。

各調查地点における水深と光減衰率との関係を 図-5に示す. また, 各地区の光減衰率曲線からハ夕 八夕産卵場（藻場）の水深帯に対応した光減衰率を 表-2に示す.なお, えりものデー夕については, 既 往調查結果 ${ }^{10}$ ) による産卵場（藻場）の水深帯と近 接の様似漁港 ${ }^{11)}$ の光減衰率曲線を用いている. 産 卵海藻であるウガノモクなどは, 苫小牧東港内防波 堤周辺では水深 $0.5 \sim 4.0 \mathrm{~m}$, 根室海域では $2.0 \sim 8.7 \mathrm{~m}$, えりも海域（天然）では4.0〜9.0mに分布しており 分布下限水深は異なる. しかし, 海藻類の光合成に 大きく関係する光減衰率に着目すると, 海域の違い に関係なく概ね $20.05 \sim 0.09$ 以上の水深帯に分布して いる。

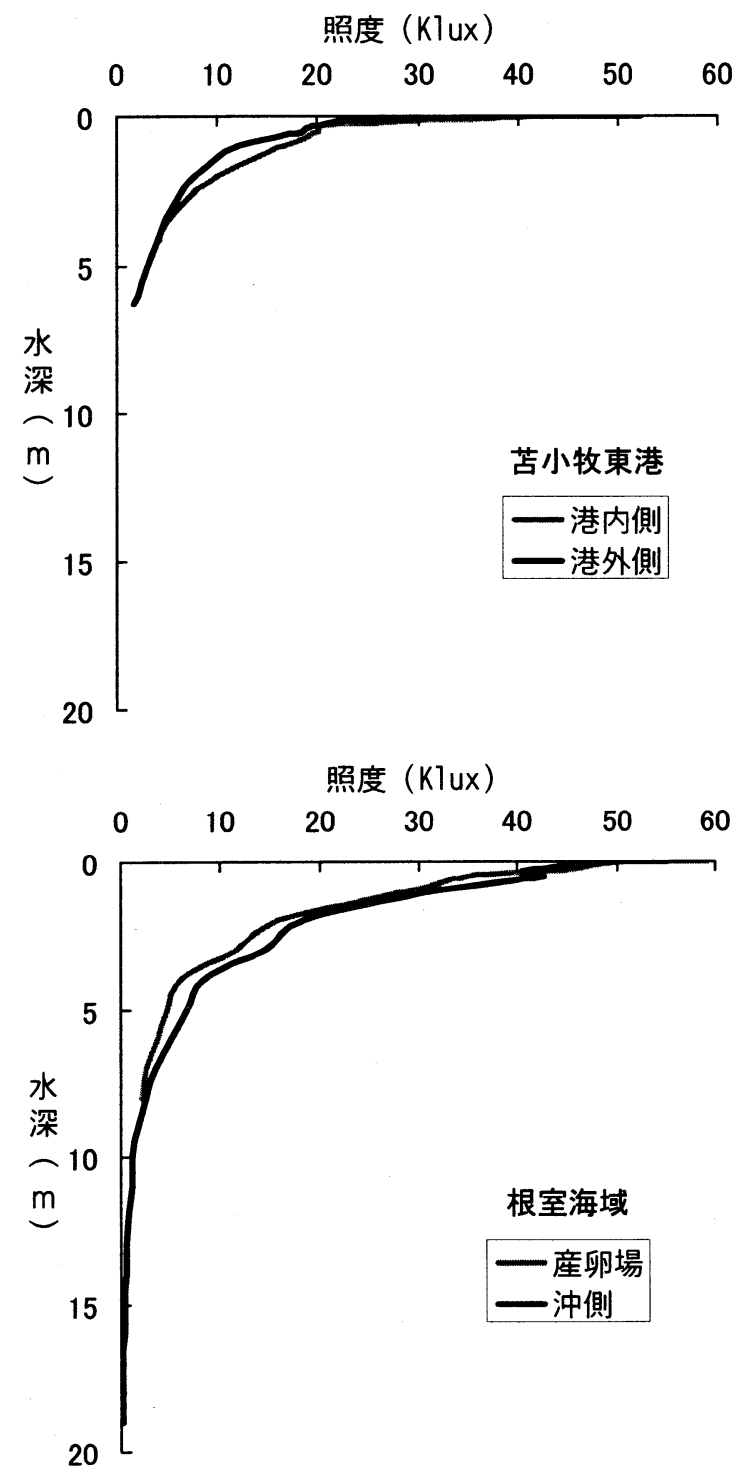

図-4 水深と照度の関係
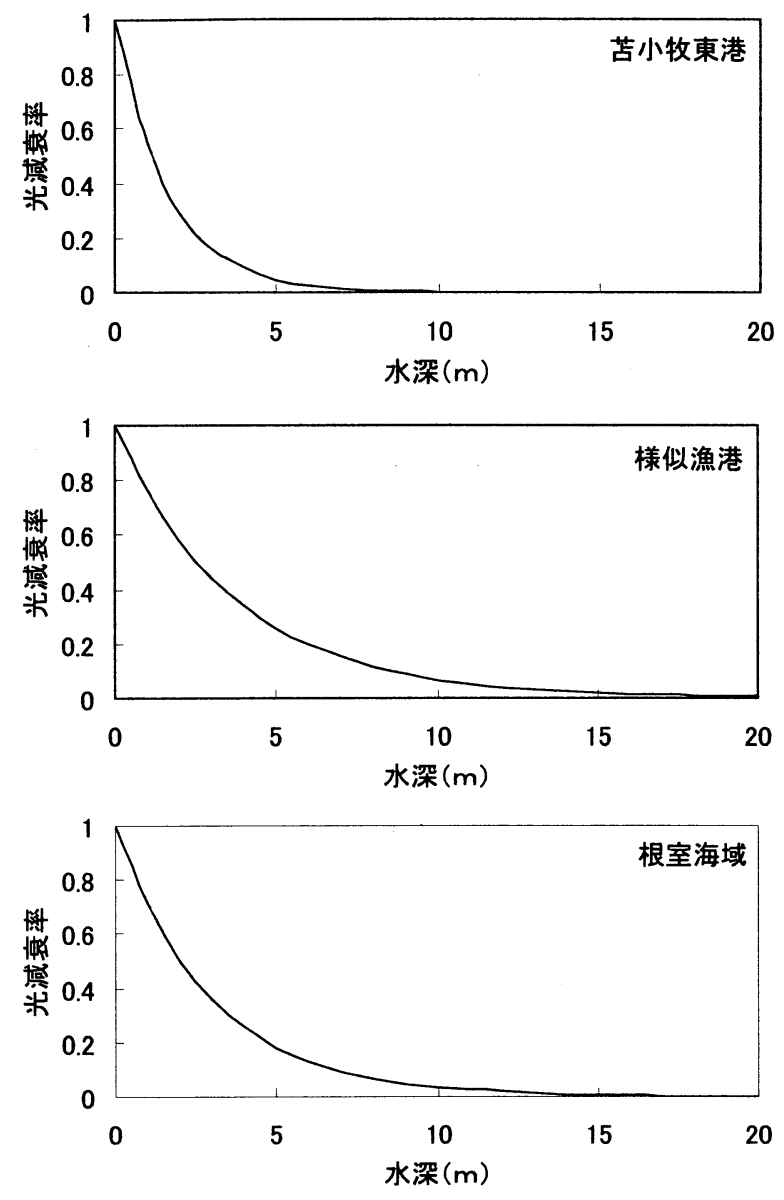

図 -5 水深と光減衰率の関係

\begin{tabular}{|c|c|c|c|}
\hline \multicolumn{4}{|c|}{ 表 -2 産卵場(藻場)の光減衰率 } \\
\hline 調查箇所 & 藻 場 & 藻場分布水深 & 光減衰率範囲 \\
\hline & ウガノモク & $0.5 \sim 4.0 \mathrm{~m}$ & $0.74 \sim 0.09$ \\
\hline 客 & アカモク & $0.5 \sim 3.0 \mathrm{~m}$ & $0.74 \sim 0.16$ \\
\hline えりも海域 & ウガノモク & $4.0 \sim 9.0 \mathrm{~m}$ & $0.45 \sim 0.09$ \\
\hline 根室海域 & ネブトモク & $2.0 \sim 8.7 \mathrm{~m}$ & $0.51 \sim 0.05$ \\
\hline
\end{tabular}

（3）波浪調查結果

桑原ら ${ }^{12)}$ はウガ, モクの幼胚の着生に関し, 回 転盤を用いた室内実験から「ウガノモクの幼胚のス

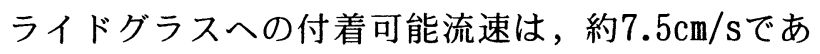
る」ことを示している. また，この実験において， 回転盤の中心軸に近いほど付着個体数が多いことか ら, 流速が小さいほど付着個体数が多いと考えられ る. しかし, 浮泥が多い海域では流速が著しく小さ い場合, 基質上を浮泥が覆ってしまい幼胚の付着が 妨げられることが考えられる.

各海域の $50 \%$ 未超過流速を図-6に示す. 八夕ハ夕 の産卵時期の流速を比較すると, 苫小牧東港（12 月）は $2.5 \mathrm{~cm} / \mathrm{s}$ 以下であるが, 根室海域 (12月) は 約 $20 \mathrm{~cm} / \mathrm{s} て ゙ あ り ， 2$ 地点間で大きく異なっている. このことから，ハ夕ハ夕産卵場の付加を検討する場 合, 産卵時期の流速はそれほど重要でないと考えら れる。

しかし， ウガノモクの幼胚の着生時期である6 7 月で比較すると, その時期の流速は2地点間とも同 程度であり, ウガノモクの幼胚の着生可能流速であ 
る7.5cm/s以下 ${ }^{12)}$ であった。このことから，ハ夕ハ 夕産卵場の付加を検討する場合, 産卵時期の冬期で はなく, 産卵海藻の幼胚の着生時期である夏期の流 速に着目する必要があると考えられ，その時期には 静穏な波浪環境が必要であると考えられる。なお， 根室海域でのハ夕ハ夕の産卵海藻であるネブトモク については, ウガノモクと同じホンダワラ類のウガ ノモク科に属することから，ほぼ同様の生態特性で あるものと考えた。

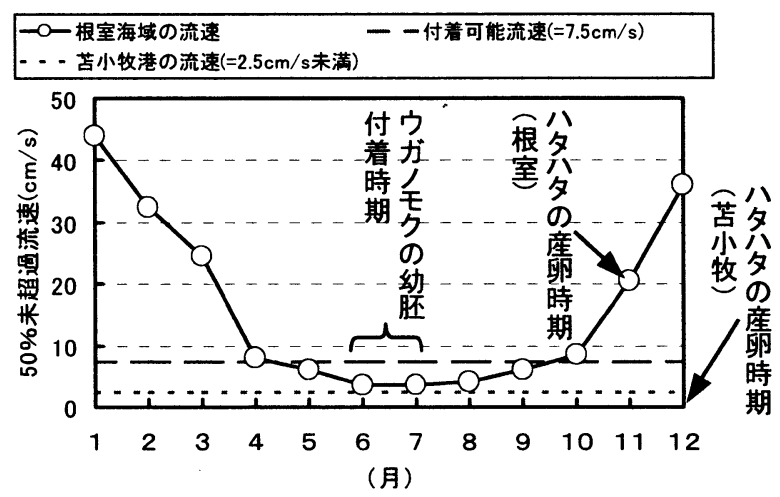

図－6＼cjkstart各海域の $50 \%$ 未超過流速

\section{5.おわりに}

防波堤にハ夕ハ夕の産卵が確認されている苫小牧 東港と天然産卵場として知られている根室海域を対 象として行った現地調查結果をもとに，八夕ハ夕産 卵場の光と流れに着目し検討を行った結果をまとめ ると以下のようになる。

(1)ハ夕ハ夕は産卵回遊経路上に産卵海藻となるホン ダワラ類が分布していれば，水深帯に関係なく産卵 すると考えられる。

(2)八夕ハ夕の産卵海藻であるウガノモクなどは, 苫 小牧東港と根室海域では分布下限水深は異なるが, 光減衰率は概ね $0.05 \sim 0.09$ 以上の水深帯に分布して
いる.

(3)八夕ハ夕産卵場の流速は, 産卵時期よりもホンダ ワラ類の幼胚の着生時期の流速が重要であると考え られる。

\section{参考文献}

1)伊東公人, 永田晋一郎, 津村憲, 谷野賢二: 沿岸構造 物における魚類産卵場の可能性〜ハ夕ハ夕を対象とし て〜，海洋開発論文集，第15巻，pp.159-163，1999.

2)杉山秀樹：ハ夕ハ夕は藻場がふるさと, マニア, No.239, pp.58-61，1992.

3) 今野敏徳, 泉伸一, 竹内慎太郎 : 漸深帯大型海藻の帯 状分布に及ぼす波浪の影響, 東京水産大学研究報告, 72巻,2号, pp.85-97, 1985.

4) 杜多哲, 飯倉敏弘, 北村章二 : ホンダワラ類幼肧の着 生数の分布と波の影響, 55 巻, 7号, pp.1161-1172, 1989.

$5)$ 北海道立中央水産試験場研究員 : 漁業生物図鑑「北の さかなたち」, 北日本海洋センター, pp.132, 1991.

6 ) 水産庁中央水産研究所水産研究官: 藻場の機能, 水産 庁中央水産研究所, pp.57, 1997.

7) 丸伊満, 稲井宏臣, 吉田忠生 : 北海道忍路湾における ホンダワラ類の成長と成熟について, 藻類, 29 巻, pp.227-281, 1981 .

8) 北海道開発局港湾部 : 平成 5 年度港湾 - 漁港波高出現 率算定業務資料集, 1993 .

9) 日本水産資源保護協会 : 環境が海藻類に及ぼす影響を 判断するための判断基準と事例, pp.49，1992.

$10)$ 北海道立函館水産試験場 : 八夕八夕産卵回帰群生生態 調查, 平成10年度事業報告書, pp.87-94, 2000 。

11)佐々木秀郎, 竹田義則, 北原繁志, 鳴海日出人, 袖野 宏樹: 沿岸構造物における海藻群落形成に必要な光と 流れに関する研究, 海岸工学論文集, 第 45 巻, pp.1166-1170, 1998.

12)桑原久美, 金田友紀, 川井唯史 : 波浪によるウガノモ クの幼肧および成体の基質付着限界，海岸工学論文集， 第46巻, pp.1146-1150, 1999.

13)水産庁漁港部監修: 自然調和型漁港づくり技術マニュ アルー藻場機能の付加一, pp.12，1999. 